\title{
KEJADIAN KEGUGURAN DITINJAU DARI UMUR IBU DI BPS ITA ARIANI WONOAYU SIDOARJO
}

\author{
Ika Mardiyanti \\ Fakultas Keperawatan dan Kebidanan \\ Universitas Nahdlatul Ulama Surabaya Jl. Smea 57 Surabaya \\ Email: ika_mardiyanti@unusa.ac.id
}

\begin{abstract}
The incidence of Abortion in terms of the maternal age in The Private Midwife Clinic of Ita Ariani Wonoayu Sidoarjo. Maternal Mortality Rate in Indonesia is still high about 206 over 100.000 life births. Abortion is one of the cause of maternal mortality rate. And pregnant mother who had age ( $<20$ and $>35$ tahun years old) is more get abortion. The purpose of this research is to analyze the correlation between maternal age with the occurance of abortion in The Private Midwife Clinic of Ita Ariani Wonoayu Sidoarjo. Design of this research is observational analytic using cross sectional method. Population of this research is 15 pregnant mothers with pregnancy age less than 20 weeks. Sample of this research as many as 14 people with simple random sampling technique. The independent variable is maternal age and the dependent variable is occurance of abortion. The data is collected from medical record and analyzed by using Chi - Square test. Result of this research show that most of respondents are pregnant mother who had low risk age $(20$ - 35 years old) as many as 8 people $(57,1 \%)$ and pregnant mother who got abortion as many as 5 people $(35,7 \%)$. Based from Chi-Square test show that $\mathrm{P}=0,001<\alpha=0,05$ and it is mean that there is correlation between mother age with the occurance of abortion. The conclusion of this research is mother age is one of the cause of abortion. Pregnant mother who had younger age (< 20 years old) and older age (> 35 years old), the probability of abortion is higher so pregnant mother must do ANC regularly.
\end{abstract}

Abstrak : Kejadian keguguran ditinjau dari umur ibu di BPS Ita Ariani Sidoarjo. Angka Kematian Ibu di Indonesia masih tinggi yaitu 206 per 100.000 kelahiran hidup. Abortus adalah salah satu penyebab angka kematian ibu. Ibu hamil berusia $(<20$ tahun dan $>35$ tahun) lebih beresiko mengalami keguguran. Tujuan penelitian ini menganalisis hubungan umur ibu dengan kejadian keguguran BPS Ita Ariani Wonoayu Sidoarjo. Desain penelitian adalah analitik observasional dengan cross sectional. Populasi sebesar $15 \mathrm{ibu}$ hamil dengan umur kehamilan kurang dari 20 minggu, besar sampel sebesar 14 orang secara simple random sampling. Variabel independen umur ibu, variabel dependen kejadian keguguran. Pengambilan data dari rekam medis, dianalisis menggunakan uji statistik Chi-Square. Hasil penelitian sebagian besar ibu hamil dengan umur resiko rendah (20 - 35 tahun) sebanyak 8 orang $(57,1 \%)$ dan ibu hamil yang mengalami keguguran sebanyak 5 orang $(35,7 \%)$. Hasil uji Chi - Square menunjukkan $P$ $=0,001<\alpha=0,05$ berarti ada hubungan antara umur ibu dengan kejadian keguguran. Simpulan dari penelitian ini adalah umur ibu merupakan faktor yang mempengaruhi terjadinya keguguran. Semakin muda $(<20$ tahun) dan semakin tua umur ibu saat hamil ( $>$ 35 tahun), kemungkinan terjadi abortus semakin tinggi sehingga ibu hamil harus melakukan ANC lebih teratur. 


\section{Kata Kunci : Kejadian keguguran, Umur, Ibu Hamil}

\section{PENDAHULUAN}

Angka kematian ibu di Indonesia saat ini tergolong masih cukup tinggi yaitu mencapai 226 per 100.000 kelahiran hidup berdasarkan hasil Survei Demografi Kesehatan Indonesia (SDKI) pada tahun 2007. Walaupun Angka Kematian Ibu di Indonesia telah mengalami penurunan dari angka 307 per 100.000 kelahiran pada tahun 2004 . Dan pada tahun 2010 Angka Kematian Ibu sebesar 226 per 100.000 Kelahiran Hidup. Kasus kematian ibu melahirkan di Indonesia masih tergolong cukup tinggi. Padahal berdasarkan Sasaran Pembangunan Milenium atau Millenium Development Goals (MDGs), angka kematian ibu ditetapkan pada angka 102 per 100.000 kelahiran pada tahun 2015 . Angka kematian ibu di Indonesia paling tinggi di Asia (Propiona, 2010).

Kematian ibu di Indonesia disebabkan oleh komplikasi obstetri yang meliputi perdarahan (28\%), pre eklampsia dan eklampsia (24\%), infeksi (11\%), abortus (5\%), dan partus lama $(5 \%)$. Perdarahan dapat terjadi saat kehamilan, persalinan, dan masa nifas (Yono, 2011). Perdarahan yang terjadi saat kehamilan bisa dikarenakan abortus, Kehamilan Ektopik Terganggu (KET), dan Ante Partum Bleeding (APB).

Menurut definisinya keguguran atau abortus adalah berakhirnya suatu kehamilan sebelum kehamilan berumur 20 minggu dengan berat janin kurang dari 500 gr (Prawirohardjo, 2007). Sekitar 50-75\% dari konsepsi mengalami abortus secara spontan. Sebagian besar diantaranya tidak dikenali karena terjadi sebelum atau pada saat menstruasi selanjutnya. 15$20 \%$ dari kehamilan yang didiagnosis secara klinis mengalami abortus spontanea. Kejadian keguguran di Indonesia setiap tahun terjadi 2 juta kasus. Ini artinya terdapat 43 kasus abortus per 100 kelahiran hidup. (Yudia, 2008).

Kejadian keguguran dapat disebabkan oleh banyak faktor diantaranya ialah kelainan pertumbuhan hasil konsepsi, kelainan pada plasenta dan penyakit pada ibu, serta faktor eksternal. Adapun faktor predisposisi terjadinya abortus yaitu jumlah graviditas, umur ibu, penyakit ibu yang melemahkan, infeksi, paparan lingkungan, dan trauma fisik maupun emosional. Dengan asumsi bahwa semakin tua umur ibu maka semakin tinggi angka kejadian abortus dan semakin muda (dibawah 20 tahun) umur ibu maka angka kejadian keguguran akan semakin tinggi pula. Sedangkan menurut Yudia (2008), umur ibu yang sudah tua menjadi faktor yang mempengaruhi terjadinya abortus spontan disamping faktor risiko lain seperti graviditas, riwayat keguguran, maupun kebiasaan merokok.

Resiko keguguran spontan tampak meningkat dengan bertambahnya umur terutama setelah umur 30 tahun, baik kromosom janin itu normal atau tidak, wanita dengan umur lebih tua, lebih besar kemungkinan keguguran baik janinnya normal atau abnormal. Semakin lanjut umur wanita, semakin tipis cadangan telur yang ada, indung telur juga semakin kurang peka terhadap rangsangan gonadotropin. Makin lanjut umur wanita, maka resiko terjadi abortus makin meningkat karena menurunnya kualitas sel telur atau ovum dan meningkatnya resiko kejadian kelainan kromosom. Pada gravida tua terjadi abnormalitas kromosom janin sebagai salah satu faktor etiologi abortus (Gepe, 2009). 
Komplikasi yang dapat terjadi akibat abortus adalah perdarahan, perforasi uterus pada saat pengerokan (kuretase), infeksi yang biasanya terjadi pada abortus inkomplit serta syok yang disebabkan oleh perdarahan (Yono, 2011). Sedangkan menurut Mirza (2008), penyulit-penyulit pada abortus diantaranya yaitu perdarahan, perforasi uterus, infeksi, perlekatan kavum uteri, dan luka pada serviks uteri.

Untuk mencegah terjadinya kejadian abortus, petugas kesehatan dapat memberikan penyuluhan tentang pendidikan seks yang benar, keteraturan periksa kehamilan pada tenaga kesehatan, dan penggunaan alat kontrasepsi untuk menghindari terjadinya kehamilan pada umur-umur yang termasuk resiko tinggi untuk kehamilan.

Dari data register di BPS Ita Ariani Wonoayu Sidoarjo pada tahun 2011, didapatkan bahwa kejadian keguguran ada 4 kasus. Sedangkan pada tahun 2012 meningkat menjadi 5 kasus.

Dari 5 wanita yang mengalami keguguran pada tahun 2012, sebanyak 2 wanita $(40 \%)$ berumur $20-35$ tahun, sedangkan 3 wanita $(60 \%)$ berumur $<20$ tahun dan $>35$ tahun.

Berdasarkan uraian di atas, maka penulis tertarik untuk melakukan penelitian tentang hubungan antara umur ibu dengan kejadian keguguran di BPS Ita Ariani Wonoayu Sidoarjo.

\section{METODE}

Desain yang digunakan adalah analitik observasional pendekatan yang digunakan dalam penelitian ini adalah cross sectional, yaitu dimana di observasi hanya sekali saja. Populasi dalam penelitian ini adalah semua ibu hamil dengan umur kehamilan kurang dari sama dengan 20 minggu yang berkunjung di BPS Ita Ariani Wonoayu Sidoarjo pada bulan Januari - Desember 2013 sebesar 15 orang. Sampel dalam penelitian ini adalah sebagian ibu hamil dengan umur kehamilan kurang dari sama dengan 20 minggu di BPS Ita Ariani Wonoayu Sidoarjo Januari Desember 2013 sebesar 14 orang. Tehnik sampling dilakukan secara probability sampling, tehnik yang digunakan adalah simple random sampling yaitu pengambilan sampel secara acak sederhana dimana setiap anggota atau unit dari populasi kesempatan yang sama untuk dijadikan sampel dengan cara acak. Variabel independent adalah umur ibu dan variabel dependent adalah kejadian keguguran.

Data dianalisis dengan menggunakan uji statistik Chi Square dengan tingkat kemaknaan $\alpha=0,05 . \mathrm{H}_{0}$ ditolak jika $\mathrm{p}<\alpha$ berarti ada pengaruh antara umur ibu dengan kejadian keguguran.

\section{HASIL PENELITIAN}

Karakteristik Responden Menurut Graviditas

Tabel 1 Distribusi frekuensi berdasarkan Graviditas di BPS Ita Ariani Wonoayu Sidoarjo Desember 2013

\begin{tabular}{|c|c|c|c|}
\hline $\begin{array}{c}\text { No } \\
\text {. }\end{array}$ & Graviditas & $\begin{array}{c}\text { Frekuens } \\
\text { i }\end{array}$ & $\begin{array}{c}\text { Persentas } \\
\text { e }(\%)\end{array}$ \\
\hline 1 & Primigravida & 8 & 57,1 \\
\hline 2 & Multigravida & 4 & 28,6 \\
\hline 3 & $\begin{array}{c}\text { Grandemultigravid } \\
\mathrm{a}\end{array}$ & 2 & 14,3 \\
\hline & Jumlah & 14 & 100 \\
\hline
\end{tabular}

Berdasarkan tabel 1 dapat diketahui dari 14 responden sebagian besar $(57,1 \%)$ merupakan primigravida.

Karakteristik Responden Menurut Pekerjaan

Tabel 2 Distribusi frekuensi berdasarkan pekerjaan di BPS Ita Ariani Wonoayu Sidoarjo Desember 2013 


\begin{tabular}{llcc}
\hline No. & Pekerjaan & Frekuensi & $\begin{array}{c}\text { Persentase } \\
(\%)\end{array}$ \\
\hline 1 & IRT & 6 & 42,9 \\
2 & Swasta & 7 & 50 \\
3 & PNS & 1 & 7,1 \\
\hline Jumlah & 14 & 100 \\
\hline
\end{tabular}

Berdasarkan tabel 2 dapat diketahui bahwa dari 14 responden setengahnya (50\%) bekerja swasta.

Karakteristik Responden Menurut Pendidikan

Tabel 3 Distribusi frekuensi berdasarkan pendidikan di BPS Ita Ariani Wonoayu Sidoarjo Desember 2013

\begin{tabular}{llcc}
\hline No. & Pendidikan & Frekuensi & $\begin{array}{c}\text { Persentase } \\
(\%)\end{array}$ \\
\hline 1 & Dasar & 7 & 50 \\
2 & Menengah & 5 & 35,7 \\
3 & Tinggi & 2 & 14,3 \\
\hline Jumlah & 14 & 100 \\
\hline
\end{tabular}

Berdasarkan tabel 3 dapat diketahui bahwa dari 14 responden setengahnya (50\%) memiliki pendidikan dasar.

Karakteristik Responden Menurut Riwayat Kuretase

Tabel 4 Distribusi frekuensi berdasarkan riwayat kuretase di BPS Ita Ariani Wonoayu Sidoarjo Desember 2013

\begin{tabular}{clcc}
\hline No. & $\begin{array}{c}\text { Riwayat } \\
\text { kuretase }\end{array}$ & Frekuensi & $\begin{array}{c}\text { Persentase } \\
(\%)\end{array}$ \\
\hline 1 & Pernah & 5 & 35,7 \\
2 & Tidak Pernah & 9 & 64,3 \\
\hline Jumlah & 14 & 100 \\
\hline
\end{tabular}

Berdasarkan tabel 4 dapat diketahui bahwa dari 14 responden sebagian besar $(64,3 \%)$ tidak pernah mengalami tindakan kuretase.

Karakteristik Responden Menurut Pendidikan
Tabel 5 Distribusi frekuensi berdasarkan Umur di BPS Ita Ariani Wonoayu Sidoarjo Desember 2013

\begin{tabular}{llcc}
\hline No. & $\begin{array}{l}\text { Kelompok } \\
\text { Umur }\end{array}$ & Frekuensi & $\begin{array}{c}\text { Persentase } \\
(\%)\end{array}$ \\
\hline 1 & $\begin{array}{l}\text { Resiko tinggi } \\
(<20 \text { th dan }>\end{array}$ & 6 & 42,9 \\
2 & $\begin{array}{l}\text { 35th) } \\
\text { Resiko } \\
\text { rendah (20-35 } \\
\text { th) }\end{array}$ & 8 & 57,1 \\
\hline Jumlah & 14 & 100 \\
\hline
\end{tabular}

Berdasarkan tabel 5 dapat diketahui bahwa dari 14 responden sebagian besar $(57,1 \%)$ berumur resiko rendah 20-35 tahun.

Tabel 6 Distribusi frekuensi berdasarkan Kejadian Keguguran di BPS Ita Ariani Wonoayu Sidoarjo Desember 2013

\begin{tabular}{llcc}
\hline No. & $\begin{array}{c}\text { Kejadian } \\
\text { keguguran }\end{array}$ & Frekuensi & $\begin{array}{c}\text { Persentase } \\
(\%)\end{array}$ \\
\hline 1 & Keguguran & 5 & 35,7 \\
2 & Tidak & 9 & 62,3 \\
& Keguguran & & 100 \\
\hline Jumlah & 14 & 14 \\
\hline
\end{tabular}

Berdasarkan tabel 6 dapat diketahui bahwa dari 14 responden sebagian besar $(71,4 \%)$ tidak mengalami keguguran.

Tabel 7 Tabulasi silang antara umur ibu dengan kejadian keguguran di BPS Ita Ariani Wonoayu Sidoarjo Desember 2013

\begin{tabular}{|c|c|c|c|c|c|c|c|}
\hline \multirow{3}{*}{$\begin{array}{c}\text { Kelompok } \\
\text { Umur }\end{array}$} & \multicolumn{4}{|c|}{ Kejadian keguguran } & \multirow{2}{*}{\multicolumn{2}{|c|}{ Total }} & \multirow{3}{*}{$\begin{array}{l}\text { Hasil } \\
\text { value }\end{array}$} \\
\hline & \multicolumn{2}{|c|}{$\mathrm{Ya}$} & \multicolumn{2}{|c|}{ Tidak } & & & \\
\hline & $\mathrm{N}$ & $\%$ & $\mathrm{~N}$ & $\%$ & $\sum$ & $\%$ & \\
\hline $\begin{array}{l}\text { Resiko } \\
\text { tinggi } \\
(<20 \text { th dan } \\
>35 \text { th })\end{array}$ & 4 & 66,7 & 2 & 14,3 & 6 & 100 & - \\
\hline $\begin{array}{l}\text { Resiko } \\
\text { rendah } \\
\text { (20-35 th) }\end{array}$ & 1 & 12,5 & 7 & 87,5 & 8 & 100 & - \\
\hline Total & 5 & 35,7 & 9 & 64,3 & 14 & 100 & 0.001 \\
\hline
\end{tabular}

Berdasarkan tabel 7 di atas menunjukkan bahwa dari 6 ibu hamil yang resiko tinggi (berumur kurang dari 
20 tahun dan lebih dari 35 tahun), sebagian besar mengalami abortus yakni sejumlah 4 orang $(66,7 \%)$. Sementara dari 8 ibu hamil yang masuk dalam kelompok resiko rendah (berumur antara 20 sampai 35 tahun), hampir seluruhnya tidak mengalami abortus yakni sejumlah 7 orang $(87,5 \%)$.

Analisis data menggunakan uji Chi-Square dengan tingkat kemaknaan $=0,05$ dihitung menggunakan alat bantu SPSS didapatkan hasil $P=0,001$ sehingga $P$ yang berarti $\mathrm{H}_{0}$ ditolak. Kesimpulan didapatkan ada hubungan antara umur ibu dengan kejadian keguguran.

\section{PEMBAHASAN}

1. Umur ibu

Berdasarkan tabel 5 dapat diketahui bahwa dari 14 responden sebagian besar $(57,1 \%)$ berumur resiko rendah 20-35 tahun. Jumlah ibu hamil yang berumur antara $20-35$ tahun lebih banyak karena memang pada umur ini wanita biasanya sudah dianggap dewasa, siap untuk menjadi ibu, dan mencapai puncak reproduksi. Dimana umur yang ideal untuk hamil adalah 20 - 30 tahun. Hal ini sesuai dengan teori Manuaba (2010), bahwa umur 20 - 30 tahun merupakan umur reproduktif sehingga organ reproduksi dapat melaksanakan fungsi kehamilan dan persalinan dengan baik.

Sedangkan hampir setengah dari responden berumur kurang dari 20 tahun atau lebih dari 35 tahun. Banyaknya ibu hamil yang berumur kurang dari 20 tahun mungkin dikarenakan kejadian menikah muda atau pernikahan dini masih marak di kalangan masyarakat terutama masyarakat pedesaan. Selain itu, banyaknya remaja yang terlibat dalam pergaulan yang salah mengakibatkan sering terjadi kehamilan yang tidak diinginkan dan kehamilan di luar nikah sehingga mau tidak mau mereka harus mempertahankan kehamilannya meskipun umur mereka belum mencapai 20 tahun. Tidak jarang pula ibu hamil berumur lebih dari 35 tahun. Kaum wanita dewasa ini telah mendapatkan kesempatan yang seluasluasnya untuk harus dikejar. Oleh sebab itu banyak wanita yang menunda kehamilan atau bahkan menunda umur menikah. Di sisi lain, selain faktor karir alasan finansial atau ekonomi dan kesiapan mental juga dijadikan alasan menunda atau membatasi kehamilan. Hal ini sesuai dengan teori Widjanarko (2009) bahwa banyak pasangan karir yang ingin menunda dulu untuk punya momongan dan alasan umum yang dipakai pasangan untuk menunda kehamilan antara lain ekonomi atau finansial, karir, dan kesiapan mental.

Akibatnya, kehamilan pertama seringkali tidak di umur yang ideal. Menurut Prawirohardjo (2007), wanita remaja pada kehamilan pertama dan wanita yang berumur diatas 35 tahun mempunyai resiko sangat tinggi apabila terjadi kehamilan dan persalinan. Hal ini sesuai dengan teori Gepe (2009) yang menyebutkan bahwa pada kehamilan < 20 tahun, keadaan alat reproduksi yang belum siap untuk menerima kehamilan akan meningkatkan terjadinya keracunan kehamilan dalam bentuk preeklampsia maupun terjadinya kejadian abortus. Sedangkan pada umur > 35 tahun, dimana pada umur tersebut terjadi perubahan pada jaringan dan alat-alat kandungan serta jalan lahir tidak lentur lagi. Selain itu ada kecenderungan didapatkan penyakit lain dalam tubuh ibu salah satunya darah tinggi maupun diabetes melitus.

\section{Kejadian Keguguran}

Berdasarkan tabel 6 didapatkan bahwa dari 14 responden ibu hamil dengan umur kehamilan kurang dari 20 
minggu, hampir setengahnya mengalami keguguran yakni sebanyak 5 orang $(35,7 \%)$. Hal ini dimungkinkan karena masih banyaknya faktor - faktor yang bisa mempengaruhi terjadinya abortus.

Diantara faktor - faktor yang mempengaruhi terjadinya keguguran salah satunya adalah pekerjaan. Berdasarkan tabel 2 dapat diketahui bahwa setengahnya (50\%) bekerja swasta. Keguguran spontan atau Abortus spontan dapat terjadi karena pada ibu yang bekerja sebagai karyawan swasta mereka dituntut untuk lebih disiplin pada peraturan di tempat kerjanya. Dan kebanyakan dari mereka melakukan mobilisasi serta mempunyai beban pekerjaan yang lebih berat sehingga hal tersebut dapat mengakibatkan kelelahan. Selain itu untuk pegawai swasta yang bekerja di lingkungan pabrik, akibat keterpaparan dari lingkungan kerjanya dapat mengakibatkan abortus. Misalnya akibat dari terpajan bahan - bahan kimia di pabrik sehingga terjadi abortus. Oleh sebab itu ibu yang hamil dan bekerja seharusnya mengurangi beban kerja yang diambilnya serta sebisa mungkin menghindari paparan lingkungan yang bisa membahayakan janinnya.

Faktor pendidikan ibu juga dapat mempengaruhi terjadinya abortus meskipun secara tidak langsung. Pendidikan sangat menentukan pengetahuan dan persepsi seseorang terhadap pentingnya suatu hal. Berdasarkan tabel 3 dapat diketahui bahwa setengahnya (50\%) memiliki pendidikan dasar. Dengan tingginya pendidikan akan berpengaruh pada sikap dan perilaku seseorang sehingga informasi yang diterima ibu dari petugas kesehatan dapat dicerna dengan baik dan diterapkan dalam kehidupan sehariharinya. Hal ini dapat mencegah terjadinya komplikasi pada kehamilan maupun terjadinya abortus. Tingkat pendidikan yang tinggi juga mempengaruhi minat ibu untuk lebih memperhatikan kondisi kehamilannya sehingga ia bersedia memeriksakan kehamilannya sesuai jadwal. Hal ini sesuai dengan teori Widjanarko (2009) yang menyatakan bahwa semakin tinggi tingkat pendidikan seseorang maka diharapkan seseorang akan semakin mudah atau terbuka dalam menyerap, memilih, dan beradaptasi dengan segala informasi dan sesuatu yang baru.

Selain itu, riwayat kuretase juga menyebabkan frekuensi terjadinya abortus. Akibat tindakan kuretase pada kehamilan sebelumnya bisa meninggalkan parut pada uterus. Dan berdasarkan tabel 4 didapatkan sebanyak $5(35,7 \%)$ ibu hamil pernah mengalami kuretase. Hal ini dapat menjadi salah satu faktor yang mempengaruhi terjadinya abortus. Riwayat tindakan kuretase dapat dihubungkan dengan terjadinya inkompetensi serviks, yang mana inkompetensi serviks merupakan salah satu faktor yang menyebabkan terjadinya abortus. Sesuai dengan teori Prawirohardjo (2007) yang menyebutkan bahwa dalam keadaan normal hasil konsepsi dipertahankan dalam kavum uteri oleh kombinasi faktor hormonal dan mekanikal. Akibat kelainan pada serviks, menyebabkan fungsi konstriksi jaringan sirkumferens fibro-muskular setinggi ostium uteri internum terganggu sehingga terjadilah herniasi atau penonjolan selaput janin tanpa disertai perasaan mules disusul dengan robekan selaput janin. Akibatnya terjadilah abortus atau partus prematurus dalam masa kehamilan awal trimester dua atau trimester tiga.

3. Kejadian keguguran ditinjau dari umur ibu

Pada tabel 7 menunjukkan bahwa dari 6 ibu hamil yang resiko tinggi (berumur kurang dari 20 tahun dan lebih dari 35 tahun), sebagian besar mengalami keguguran yakni sejumlah 4 orang 
(66,7\%). Sementara dari 8 ibu hamil dengan resiko rendah (berumur antara 20 sampai 35 tahun), hampir seluruhnya tidak mengalami keguguran sejumlah 7 orang $(87,5 \%)$.

Dari uji statistik SPSS for Windows didapatkan bahwa $P<\alpha$ sehingga $\mathrm{H}_{0}$ ditolak yang artinya ada hubungan antara umur ibu dengan kejadian keguguran. Hal ini menunjukkan bahwa semakin muda umur ibu ( $<20$ tahun) dan semakin tua umur ibu (>35 tahun), risiko terjadi keguguran semakin meningkat.

Pada ibu hamil yang berumur kurang dari 20 tahun organ reproduksinya belum matang sempurna sehingga kurang siap jika terjadi kehamilan, selain itu faktor psikologi yang belum siap untuk menjadi ibu juga memungkinkan menyebabkan terjadinya abortus. Sementara itu pada ibu hamil yang berumur lebih dari 35 tahun fungsi organ reproduksinya sudah mulai menurun sehingga jika terjadi kehamilan akan mengalami berbagai komplikasi.

Sesuai dengan teori dari Cunningham

(2006) yang menyebutkan bahwa frekuensi abortus bertambah dari 12\% pada wanita yang berumur kurang dari 20 tahun, menjadi $26 \%$ pada wanita berumur diatas 40 tahun. Kemungkinan abortus bisa dialami oleh setiap wanita pada umur berapapun. Namun pada wanita dengan umur lebih dari 30 tahun kemungkinan itu sangatlah besar dibanding di bawahnya, dan kebanyakan kejadian abortus pada umur lebih dari 30 tahun berakhir dengan abortus yang tidak bisa dipertahankan lagi.

Semakin lanjut umur wanita, semakin tipis cadangan telur yang ada, indung telur juga semakin kurang peka terhadap rangsangan gonadotropin. Makin lanjut umur wanita, maka resiko terjadi abortus makin meningkat karena menurunnya kualitas sel telur atau ovum dan meningkatnya resiko kejadian kelainan kromosom. Pada gravida tua terjadi abnormalitas kromosom janin sebagai salah satu faktor etiologi abortus. Hal lain yang perlu diperhatikan adalah kejadian tumor leiomioma uteri pada ibu dengan umur lebih tinggi dan lebih banyak sehingga dapat menambah risiko terjadinya abortus (Gepe, 2009).

\section{SIMPULAN}

1. Ibu hamil yang berkunjung di BPS Ita Ariani Wonoayu Sidoarjo sebagian besar berumur resiko rendah (20 sampai 35 tahun).

2. Ibu hamil yang berkunjung di BPS Ita Ariani Wonoayu Sidoarjo sebagian besar tidak mengalami abortus.

3. Ada hubungan umur ibu dengan kejadian keguguran di BPS Ita Ariani Wonoayu Sidoarjo.

\section{DAFTAR PUSTAKA}

Cunningham, dkk. (2006). Obstetri Williams. Jakarta, EGC.

Gepe (2009). Hubungan Usia Ibu dengan Kejadian Abortus. www.gepe2306.blog.Artikel diakses tanggal 11 September 2013.

Manuaba, IGB, dkk. (2010). Ilmu Kebidanan, Penyakit Kandungan, dan Keluarga Berencana untuk Pendidikan Bidan. Jakarta, EGC.

Mirza, Maulana (2008). Penyakit Kehamilan dan Pencegahannya. Yogyakarta, Katahati.

Prawirohardjo, Sarwono (2007). Ilmu Kebidanan. Jakarta, YBPSP.

Propiona (2010). Permasalahan Masih Tingginya Angka Kematian Ibu di Indonesia. www.propionagreat.blog. Artikel 
diakses tanggal 25 Agustus 2013.

Widjanarko, Bambang (2009). Informasi Reproduksi, Abortus. www.bewe.blog. Artikel diakses tanggal 19 September 2013.

Yono (2011). Hubungan Paritas dan Umur Ibu dengan Kejadian
Abortus. www.yonokomputer.com. Artikel diakses tanggal 25 Oktober 2013.

Yudia (2008). Abortus. www.yudiayutz.wordpress.com. Artikel diakses tanggal 19 Agustus 2013. 